\title{
Pilihan dan Persepsi Risiko terhadap Jenis Sumber Air Minum pada Masyarakat Kumuh Perkotaan di Bantaran Sungai Cikapundung Kota Bandung
}

\author{
Sri Yusnita Irda Sari, Ardini Raksanagara \\ Departemen Ilmu Kesehatan Masyarakat \\ Fakultas Kedokteran Universitas Padjadjaran Bandung, Indonesia
}

\begin{abstract}
Abstrak
Sistem penyaluran air di wilayah kumuh perkotaan sangat terbatas dan tidak dapat diandalkan baik kuantitas dan kualitas terutama di negara-negara berkembang. Pilihan terhadap jenis sumber air dan tipe pengolahan akan berdampak pada status kesehatan masyarakat. Penelitian ini bermaksud menggali hubungan faktor demografi dan persepsi risiko terhadap pilihan sumber air minum pada masyarakat kumuh perkotaan. Studi potong lintang dilaksanakan pada bulan September-Oktober 2015 pada masyarakat kumuh perkotaan di 20 RW yang berada di bantaran sungai Cikapundung Kota Bandung. Sampel dipilih dengan metode acak sistematis. Data dikumpulkan melalui kuesioner dan kualitas sampel air minum diperiksa dengan Suncoli test kit untuk mendeteksi dan menghitung jumlah bakteri Coliform. Jenis air minum yang dikonsumsi masyarakat kumuh perkotaan adalah merebus air minum yang bersumber air sumur dan air perpipaan atau membeli air minum dalam kemasan. Faktor yang berhubungan dengan pilihan jenis air minum yang dikonsumsi adalah faktor status ekonomi, ketersediaan jenis sumber air bersih yang dimiliki, dan faktor pendidikan kepala keluarga $(p<0,001)$. Persepsi terhadap risiko keamanan sumber air bersih berhubungan dengan pilihan jenis sumber air minum yang dikonsumsi $(p<0,001)$. Upaya promosi kesehatan mengenai cara pengolahan air minum perlu ditingkatkan dan perbaikan penyediaan air perpipaan harus diupayakan.
\end{abstract}

Kata kunci: Air minum, masyarakat kumuh, perkotaan, persepsi risiko

\section{Choice and Risk Perception on Drinking Water source among Urban Slum Dwellers Living on Cikapundung River Basin in Bandung City}

\begin{abstract}
s
Water supply system in urban slum area is often unreliable in terms of water quality and quantity, particularly in developing countries. Choices on the type of water source and water treatment may be associated with public health outcomes. This study aimed to investigate correlation between demographic factors and risk perception on the choice of water source type in urban slum area. A cross-sectional study was conducted during September-October 2015 in 20 neigborhood (Rukun Warga, RW) living on Cikapundung river basin in Bandung City. Households were sampled using systematic random sampling method. Data were collected through a questionnaire and water quality was assessed using Suncoli test kit to examine total Coliform level in drinking water. Drinking water consumed by the urban slum dweller included boiled water from ground well and piped water as well as commercial drinking water. Factors influencing the choice of drinking water were economic status, availability of clean water source, and education level of head of household $(\mathrm{p}<0.001)$. Perception towards health risks carried by clean water correlates with the choice of drinking water to be consumed $(p<0.001)$. Health promotion efforts on how to process drinking water need to be improved and piped water provision should be improved.
\end{abstract}

Key words: Drinking water, risk perception, slum dweller, urban

Korespondensi: Dr. Sri Yusnita Irda Sari, dr., MSc, Departemen Ilmu Kesehatan Masyarakat Fakultas Kedokteran Universitas Padjadjaran, Jalan Eyckman No.38 Bandung,Email: italatif@yahoo.com, sri.yusnita@unpad.ac.id 


\section{Pendahuluan}

Air merupakan kebutuhan yang sangat penting untuk kehidupan manusia, namun jumlah air yang dapat diminum semakin terbatas sehingga sistem penyaluran air sangatlah berpengaruh dalam kehidupan masyarakat. Masyarakat yang hidup di negara-negara maju dapat memperoleh air bersih melalui sistem penyaluran air yang sudah disiapkan sehingga tidak perlu melakukan upaya pengolahan air sendiri. Berbeda dengan negara-negara berkembang, sistem penyaluran air sangat terbatas dan tidak dapat diandalkan baik dari segi kuantitas dan kualitas terutama di wilayah kumuh perkotaan. Masyarakat mengonsumsi air minum dari berbagai macam sumber air bersih seperti air tanah, air sungai, air hujan atau air dalam kemasan. Selain itu, masyarakat juga harus dengan cermat memilih jenis pengolahan air yang mereka pakai, apakah dengan merebus, dengan cara filtrasi, klorinasi, atau membeli air minum dalam kemasan (AMDK).

Pilihan terhadap jenis sumber air dan tipe pengolahan air akan berdampak pada status kesehatan masyarakat. Penelitian yang terdahulu menggambarkan bahwa prevalensi penyakit tular air berhubungan dengan pilihan jenis air minum, masyarakat yang meminum AMDK lebih jarang yang mengalami diare. ${ }^{1}$ Pengolahan air minum dengan cara direbus masih merupakan salah satu cara yang efektif. ${ }^{2}$

Beberapa penelitian melaporkan faktorfaktor demografi yang memengaruhi pemilihan jenis sumber air minum adalah faktor usia, tingkat pendidikan, dan juga pendapatan baik di negara maju atau negara berkembang. ${ }^{3-6}$ Penelitian lain melaporkan tentang persepsi masyarakat akan risiko dan keamanan sumber air yang dikonsumsi dengan pemilihan sumber air minum yang dikonsumsi, contohnya pada individu yang takut akan kualitas air perpipaan atau bersumber PDAM (Perusahaan Daerah Air Minum) maka mereka akan cenderung memilih AMDK sebagai pilihan sumber air minumnya.,

Persepsi akan risiko dapat dipengaruhi oleh beberapa faktor lain seperti rasa air dan bau yang tercium, pengalaman buruk sebelumnya yang dialami serta ketakutan akan pencemaran bakteri dan bahan kimia tertentu. ${ }^{7}$ Faktor demografi juga dapat memengaruhi persepsi risiko seperti orang berusia lebih muda cenderung merasa takut untuk meminum air perpipaan apabila dibanding dengan orang yang lebih tua.

Penelitian sebelumnya banyak dilakukan di negara maju yang telah mengonsumsi sumber air yang aman dikonsumsi tersedia untuk semua lapisan masyarakat. Sampai saat ini belum ada penelitian yang menggali hubungan antara faktor demografi dan persepsi risiko terhadap pilihan sumber air minum di negara berkembang yang biasa menggunakan sumber air sangat beragam dengan kualitas yang belum terjamin. Upaya eksplorasi mengenai hal ini akan sangat membantu para pembuat kebijakan dalam melakukan upaya perbaikan sistem penyediaan sumber air minum bagi masyarakat.

Pengolahan air dengan cara merebus sudah lama dipraktikkan dan masih banyak dilakukan oleh masyarakat di Indonesia, ${ }^{8}$ sementara AMDK dan air minum isi ulang juga menjamur sejak beberapa dekade terakhir. Sampai saat ini diare masih menjadi salah satu angka kejadian dan kematian balita sehingga kepastian akan penyediaan air bersih menjadi masalah yang penting di Indonesia.

Kota Bandung sebagai ibukota Provinsi Jawa Barat mengalami urbanisasi yang cepat sehingga penambahan jumlah penduduk juga secara tidak langsung sudah memengaruhi kondisi lingkungan termasuk tingginya kontaminasi sumber air. ${ }^{9}$ Penelitian ini bertujuan mengetahui hubungan antara faktor demografi dan perilaku masyarakat dalam memilih sumber air minum serta mengeksplorasi persepsi risiko masyarakat terhadap kualitas air minum yang dikonsumsi terutama pada masyarakat kumuh perkotaan di bantaran sungai yang mempunyai tingkat risiko pencemaran pada sumber air sangat tinggi. Pemahaman akan faktor-faktor yang memengaruhi pemilihan jenis sumber air yang digunakan masyarakat akan sangat berguna untuk upaya peningkatan promosi kesehatan untuk masyarakat.

\section{Metode}

Penelitian ini dilakukan menggunakan rancangan potong lintang, yang dilaksanakan pada bulan September-Oktober tahun 2015 di Kelurahan Tamansari yang merupakan salah satu wilayah kumuh di Kota Bandung yang berlokasi di tengah kota dan berada di bantaran Sungai Cikapundung. Sungai ini telah lama dikenal sebagai salah satu sungai yang sangat kotor yang membelah Kota Bandung. Kontaminasi sungai umumnya disebabkan oleh limbah kotoran manusia dari buangan penduduk di bantaran sungai yang tidak memiliki tangki septik sehingga langsung disalurkan ke sungai. 
Subjek penelitian ini adalah semua rumah tangga yang berada di 20 RW wilayah bantaran sungai Cikapundung Kelurahan Tamansari, Kecamatan Bandung Wetan, Kota Bandung. Sampel penelitian ditentukan dengan metode sampel acak sistematis, yaitu dengan cara menentukan rumah ketua RW sebagai titik awal. Selanjutnya dipilih sampel dari rumah yang berjarak 2 rumah dari titik awal dan seterusnya berpindah searah jarum jam sampai jumlah sampel terpenuhi. Jumlah minimal sampel ditentukan dengan rumus proporsi dengan alpha $5 \%$ dan beta $20 \%$ sehingga didapatkan minimal 384 sampel.

Responden penelitian ini merupakan anggota rumah tangga yang mengetahui mengenai pemakaian air bersih di rumah tersebut. Data yang sudah dikumpulkan melalui kuesioner berisi mengenai data demografi, karakteristik sosioekonomi, penggunaan sumber air serta persepsi responden, sedangkan data mengenai kualitas sumber air akan diketahui melalui uji laboratorium terhadap sampel air yang diambil dari semua sumber air yang digunakan di rumah responden.

Data dianalisis memakai software R-study versi 3.1.2 untuk menguji hubungan antara variabel tergantung, yaitu pilihan sumber air minum dengan berbagai variabel bebas, yaitu status demografi (pengeluaran per bulan, jumlah anggota keluarga, sumber air bersih, lama tinggal, usia, dan pendidikan kepala keluarga) dan persepsi risiko terhadap keamanan kualitas sumber air yang dimiliki baik terhadap air susia maupun PDAM. Setiap responden penelitian menerima informasi yang lengkap mengenai penelitian ini dan telah menandatangani lembar persetujuan sebelum dilakukan pengambilan data. Persetujuan etik diperoleh dari Komite Etik Fakultas Kedokteran Universitas Padjadjaran.

Kualitas air minum diperiksa menggunakan Suncoli test kit (Sun Chemical Co.,LtD, Nakano-ku Tokyo, Jepang). Metode yang digunakan adalah dengan kertas filter (Coliform detection paper) yang spesifik dapat mendeteksi dan menghitung jumlah bakteri Coliform total. Responden diminta mengambil satu gelas air minum yang dikonsumsi oleh anggota keluarga, kemudian kertas filter yang berbentuk kertas dicelupkan kedalam sampel air dan langsung disimpan dalam plastik streril pada kemasan yang telah tersedia. Kertas filter disimpan dalam cooler bag kemudian dibawa ke Laboratorium Mikrobiologi Fakultas Kedokteran Universitas Padjadjaran. Selanjutnya dimasukkan dalam inkubator $37^{\circ} \mathrm{C}$ selama 24 jam untuk melihat adanya bakteri Coliform. Keberadaan bakteri Coliform ditandai dengan timbulnya titik kemerahan pada kertas filter. Standar kualitas mikrobiologi air minum didasarkan pada pedoman yang dikeluarkan World Health Organization (WHO) dan juga Peraturan Menteri Kesehatan No 492/MENKES/ PER/IV/2010 mengenai Pedoman Kualitas Air Minum. ${ }^{10,11}$

\section{Hasil}

Sebanyak 391 responden telah berpartisipasi pada penelitian ini karakteristik responden

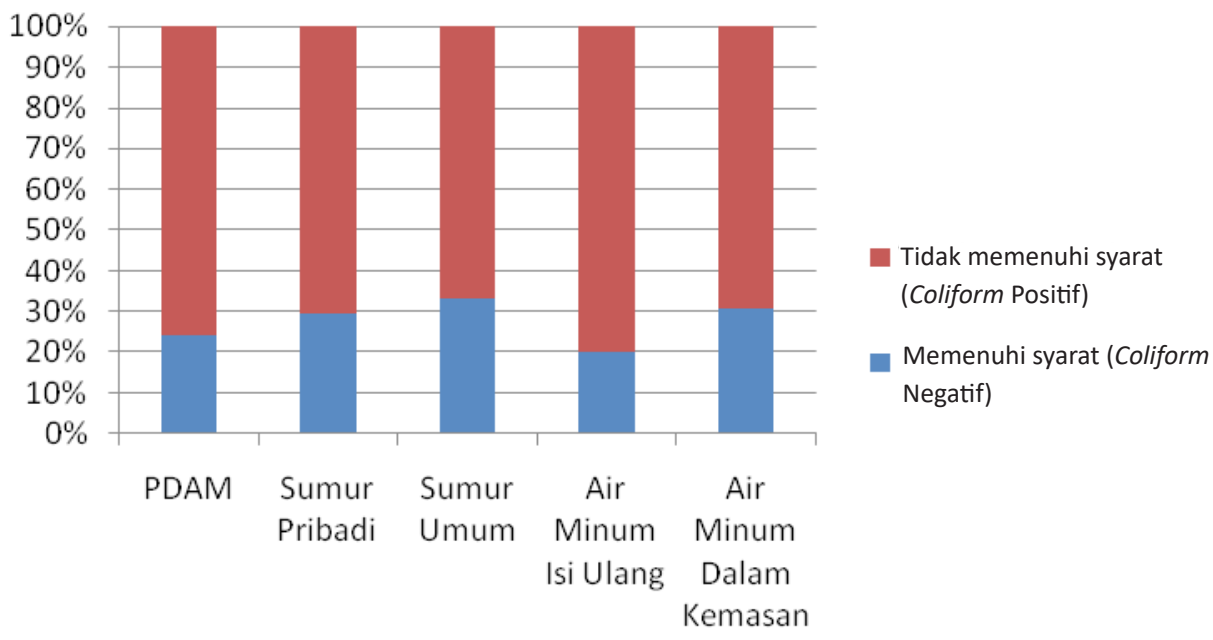

Gambar Kualitas Air Minum dari Setiap Jenis Sumber Air Minum 
Sri Y. I. Sari dkk.: Pilihan dan Persepsi Risiko terhadap Jenis Sumber Air Minum pada Masyarakat Kumuh Perkotaan di Bantaran Sungai Cikapundung Kota Bandung

Tabel 1 Karakteristik Responden

\begin{tabular}{|c|c|c|}
\hline Variabel & $\mathbf{n}$ & Rerata (Min-Maks) \\
\hline Usia (tahun) & 391 & $48(20-90)$ \\
\hline Jumlah anggota keluarga & 391 & $5(1-20)$ \\
\hline Lama tinggal di daerah ini (tahun) & 391 & $30(1-78)$ \\
\hline Pengeluaran keluarga per bulan (Rp) & 391 & $\begin{array}{c}1.775 .000 \\
(300.000-10.000 .000)\end{array}$ \\
\hline Pendidikan terakhir & & $\%$ \\
\hline SD & 101 & 25,8 \\
\hline SMP & 86 & 22 \\
\hline SMA & 157 & 40,2 \\
\hline Perguruan Tinggi & 47 & 12 \\
\hline \multicolumn{3}{|l|}{ Sumber air bersih } \\
\hline Sumur pribadi & 127 & 32,5 \\
\hline PDAM & 141 & 36 \\
\hline Sumur pribadi + PDAM & 64 & 16,4 \\
\hline Sumur umum & 59 & 15,1 \\
\hline \multicolumn{3}{|l|}{ Sumber air minum } \\
\hline Sumur pribadi & 61 & 15,6 \\
\hline PDAM & 112 & 28,7 \\
\hline Sumur umum & 30 & 7,7 \\
\hline Air isi ulang & 94 & 24 \\
\hline AMDK & 94 & 24 \\
\hline
\end{tabular}

digambarkan pada Tabel 1. Sebagian responden mempunyai tingkat pendidikan cukup baik, yaitu paling rendah sekolah menengah keadaan ini disebabkan oleh pemukiman kumuh ini terletak di tengah kota sehingga akses terhadap pendidikan cukup memadai, namun sebagian lainnya masih berpendidikan rendah hanya pendidikan dasar setingkat SD dan SMP. Rerata lama tinggal para responden adalah 30 tahun yang menunjukkan bahwa keluarga yang tinggal di sini merupakan penduduk lama dan anak atau cucu cenderung tinggal ditempat yang sama sehingga daerah ini menjadi daerah yang padat penduduk. Sumber air bersih yang digunakan bervariasi, 85\% responden menggunakan air perpipaan yang berasal dari PDAM atau air tanah/susia pribadi, namun masih didapatkan 15\% penduduk tidak mempunyai sumber air pribadi yang mengandalkan sumber air dari susia umum atau mata air umum. Setengah responden masih menggunakan teknik perebusan air untuk mengolah menjadi air minum dan sebagian penduduk lebih memilih air galon yang langsung dikonsumsi baik berupa air minum isi ulang atau AMDK.

Kualitas air minum yang telah dikonsumsi oleh responden dapat dilihat pada Gambar. Pedoman Kementerian Kesehatan Tahun 2010 maupun Pedoman WHO menyatakan bahwa air minum tidak boleh mengandung bakteri yang diindikasikan sebagai cemaran, yaitu Coliform dan Escherichia Coli sebagai indikator kontaminasi. Pada Gambar terlihat bahwa pada semua jenis sumber air minum masih mengandung bakteri Coliform. Persentase tertinggi didapat pada air minum yang bersumber pada air minum isi ulang $(79,7 \%)$. Faktor demografi yang memengaruhi pilihan jenis air minum yang dikonsumsi adalah faktor pengeluaran keluarga per bulan dan jenis sumber air bersih yang dimiliki $(p<0,001)$, sedangkan dari faktor individu kepala keluarga maka faktor yang memengaruhi jenis sumber air minum yang dikonsumsi adalah faktor pendidikan kepala keluarga $(p<0,001)$ seperti yang dijelaskan pada Tabel 2 .

Persepsi terhadap risiko keamanan sumber air bersih berhubungan dengan pilihan jenis sumber air minum yang dikonsumsi dengan $\mathrm{p}<0,001$. Pemilik sumber air bersih berupa air susia dan PDAM sebagian besar mempunyai persepsi bahwa sumber air mereka aman dikonsumsi seperti yang dijelaskan pada Tabel 3. Walapun demikian, di antara responden yang mempunyai persepsi aman sebagian tetap memilih untuk membeli air galon (baik air minum isi ulang maupun AMDK) sebagai sumber 
Sri Y. I. Sari dkk.: Pilihan dan Persepsi Risiko terhadap Jenis Sumber Air Minum pada Masyarakat Kumuh Perkotaan di Bantaran Sungai Cikapundung Kota Bandung

Tabel 2 Hubungan Status Demografi dengan Pilihan Sumber Air Minum

\begin{tabular}{|c|c|c|c|c|c|c|}
\hline & \multicolumn{5}{|c|}{ Sumber Air Minum } & \multirow[b]{2}{*}{ Nilai p } \\
\hline & PDAM & $\begin{array}{l}\text { Sumur } \\
\text { Pribadi }\end{array}$ & $\begin{array}{l}\text { Sumur } \\
\text { Umum }\end{array}$ & $\begin{array}{c}\text { Air } \\
\text { Minum } \\
\text { Isi Ulang }\end{array}$ & AMDK & \\
\hline \multicolumn{7}{|l|}{ Pengeluaran per bulan (Rp) } \\
\hline$<1.500 .000$ & 58 & 26 & 18 & 48 & 30 & \multirow{3}{*}{$\mathrm{p}<0,001$} \\
\hline $1.500 .000-2.000 .000$ & 29 & 18 & 9 & 25 & 21 & \\
\hline$>2.000 .000$ & 14 & 13 & 3 & 20 & 39 & \\
\hline \multicolumn{7}{|l|}{ Jumlah anggota keluarga } \\
\hline $1-3$ & 28 & 11 & 7 & 28 & 29 & \multirow{3}{*}{$\mathrm{p}=0,20$} \\
\hline $4-6$ & 40 & 23 & 11 & 47 & 41 & \\
\hline$>6$ & 36 & 26 & 12 & 19 & 24 & \\
\hline \multicolumn{7}{|l|}{ Sumber air bersih } \\
\hline Sumur pribadi & 7 & 57 & 9 & 27 & 33 & \multirow{4}{*}{$\mathrm{p}<0,001$} \\
\hline PDAM & 70 & 1 & 2 & 33 & 35 & \\
\hline Sumur pribadi +PDAM & 22 & 3 & 3 & 20 & 15 & \\
\hline Sumur umum & 6 & 0 & 16 & 14 & 12 & \\
\hline \multicolumn{7}{|l|}{ Lama tinggal (tahun) } \\
\hline$<12$ & 22 & 14 & 10 & 30 & 25 & \multirow{4}{*}{$\mathrm{p}=0,19$} \\
\hline $12-30$ & 24 & 13 & 6 & 22 & 28 & \\
\hline $31-44$ & 23 & 17 & 7 & 20 & 28 & \\
\hline$>44$ & 36 & 17 & 6 & 21 & 13 & \\
\hline \multicolumn{7}{|l|}{ Usia kepala keluarga } \\
\hline $20-38$ & 20 & 5 & 9 & 34 & 24 & \multirow{4}{*}{$\mathrm{p}=0,31$} \\
\hline $38-46$ & 25 & 13 & 8 & 21 & 27 & \\
\hline $46-56$ & 29 & 18 & 10 & 21 & 21 & \\
\hline$>56$ & 31 & 15 & 3 & 18 & 23 & \\
\hline \multicolumn{7}{|l|}{ Pendidikan kepala keluarga } \\
\hline SD & 33 & 17 & 9 & 30 & 11 & \multirow{4}{*}{$\mathrm{p}<0,001$} \\
\hline SMP & 24 & 15 & 5 & 23 & 19 & \\
\hline SMA & 35 & 23 & 16 & 37 & 39 & \\
\hline Perguruan Tinggi & 13 & 6 & 0 & 3 & 23 & \\
\hline
\end{tabular}

Tabel 3 Hubungan Persepsi Risiko terhadap Keamanan Kualitas Sumber Air yang Dimiliki dengan Pilihan Jenis Air yang Diminum

\begin{tabular}{|c|c|c|c|c|c|c|}
\hline \multirow{3}{*}{ Persepsi Risiko } & \multirow{3}{*}{$\mathrm{n}$} & \multicolumn{4}{|c|}{ Pilihan air minum } & \multirow{3}{*}{ Nilai-p } \\
\hline & & \multicolumn{2}{|c|}{$\begin{array}{c}\text { Merebus Air } \\
\text { Minum }\end{array}$} & \multicolumn{2}{|c|}{$\begin{array}{c}\text { Membeli Air } \\
\text { Galon }\end{array}$} & \\
\hline & & $\mathbf{n}$ & $\%$ & $\mathbf{n}$ & $\%$ & \\
\hline \multicolumn{7}{|c|}{ Terhadap air sumur } \\
\hline Aman & 119 & 58 & 48,7 & 61 & 51,3 & \multirow{2}{*}{$\mathrm{p}<0,001$} \\
\hline Tidak aman & 36 & 2 & 5,6 & 34 & 94,4 & \\
\hline \multicolumn{7}{|l|}{ Terhadap PDAM } \\
\hline Aman & 176 & 90 & 51,1 & 86 & 48,9 & \multirow{2}{*}{$\mathrm{p}=0,001$} \\
\hline Tidak aman & 21 & 3 & 14,3 & 18 & 85,7 & \\
\hline
\end{tabular}


air minum. Sebagian besar responden yang mempunyai persepsi bahwa sumber air bersih mereka tidak aman dikonsumsi maka sebagian besar lebih memilih air galon sebagai air minum.

\section{Pembahasan}

Jenis sumber air bersih dan air minum yang dikonsumsi oleh masyarakat di wilayah kumuh perkotaan ini sangat bervariasi. Hal ini berbeda dengan hasil penelitian di negara maju yang cenderung menggunakan jenis sumber air yang tetap atau terbatas disebabkan oleh kondisi di negara maju sistem distribusi air perpipaan sudah sangat baik sehingga sudah tidak ada lagi masyarakat yang memilih air tanah. ${ }^{12,13}$ Pilihan jenis air minum warga sangat dipengaruhi oleh faktor ketersediaan sumber air dan faktor status ekonomi (pengeluaran keluarga per bulan) dan pendidikan kepala keluarga sebagai pembuat keputusan. Hasil ini sesuai dengan penelitian sebelumnya di Kenya yang menyatakan bahwa pilihan masyarakat bergantung pada sumber air yang tersedia di sekitarnya. ${ }^{14}$ Masyarakat dengan status ekonomi dan pendidikan lebih tinggi cenderung akan memilih AMDK, hal ini sesuai dengan penelitian di negara maju. ${ }^{14,15}$ Tentu saja dengan harga beli yang lebih mahal maka AMDK hanya akan dipilih oleh masyarakat yang mempunyai kemampuan dan mempersepsikan bahwa AMDK mempunyai kualitas yang lebih baik.

Kontaminasi yang tinggi pada semua jenis air minum yang dikonsumsi oleh masyarakat di wilayah kumuh ini menunjukkan beberapa kemungkinan, yaitu kurang efektifnya proses perebusan air minum yang mereka lakukan atau terjadinya rekontaminasi pada air minum dari wadah yang dipergunakan baik untuk merebus, menyimpan, ataupun gelas yang digunakan karena semua wadah tersebut telah dibersihkan dengan menggunakan sumber air bersih yang terkontaminasi. Penelitian oleh Rufener $^{15}$ telah menyatakan bahwa gelas air minum dapat merupakan sumber terjadinya rekontaminasi pada air minum yang akan dikonsumsi. Pada air galon risiko rekontaminasi mungkin juga didapatkan dari dispenser atau tempat penyimpanan galon yang tidak terjaga kebersihannya atau dari galon tersebut apabila tidak dibersihkan menggunakan tisu disinfektan secara benar.

Sebagian besar dari masyarakat masih mempersepsikan bahwa sumber air tanah dan PDAM yang mereka punyai merupakan sumber air yang aman, namun sebagian dari masyarakat lebih memercayai air minum galon dibanding dengan merebus dari air tanah atau PDAM yang mereka miliki. Penelitian di negara berkembang lain menunjukkan fenomena yang sama, yaitu masyarakat mulai mengganti cara pengolahan air minum mereka dari merebus menjadi membeli air kemasan yang siap dikonsumsi. ${ }^{6}$

Kelemahan penelitian ini adalah pemeriksaan kualitas air hanya dilakukan pada sumber air minum yang dikonsumsi dan hanya melakukan pemeriksaan bakteri Coliform secara kualitatif. Penelitian lanjutan harus dilakukan dengan memeriksafecal Coliform dan Enterococci sebagai indikator kontaminasi tinja. ${ }^{16,17}$ Pemeriksaan kualitas air untuk penelitian yang selanjutnya sebaiknya dilakukan baik pada sumber air bersih maupun air minum yang dikonsumsi sehingga dapat mengukur efektivitas proses pengolahan air yang dilakukan oleh masyarakat.

Upaya promosi kesehatan terutama pada pendidikan kesehatan terkait syarat air bersih dan air minum masih harus ditingkatkan dengan memperhatikan faktor demografi dan faktor lain yang memengaruhi perilaku penggunaan air pada masyarakat, seperti faktor sikap, norma, niat dan hambatan lingkungan. ${ }^{18}$ Upaya-upaya pemerintah untuk menyediakan sumber air yang berkualitas melalui distribusi sistem perpipaan harus terus ditingkatkan agar menjadi sumber air bersih yang dapat diandalkan dan mudah diakses oleh masyarakat dengan memperhatikan water safety plan yang sesuai. ${ }^{19}$

\section{Ucapan Terima Kasih}

Penelitian ini merupakan bagian dari penelitian dengan judul "Risk Assessment on Watersource and Drinking Water Quality of Urban Slum Area in Cikapundung River Basin in Bandung Municipality" yang didanai oleh Kemenristekdikti melalui Hibah Kerjasama Luar Negeri. Penelitian ini merupakan kerjasama dengan Prof. Chiho Watanabe dari Departement Human Ecology, The University of Tokyo Jepang. Peneliti mengucapkan terima kasih kepada Yuma Matsuno dan tim peneliti lapangan serta atas bantuan segenap kader kesehatan di Kelurahan Tamansari dan staf di laboratorium Mikrobiologi FK Unpad yang telah membantu pelaksanaan penelitian ini.

\section{Daftar Pustaka}

1. Sima LC, Desai MM, McCarty KM, Elimelech 
M. Relationship between use of water from community-scale water treatment refill kiosks and childhood diarrhea in Jakarta. Am J Trop Med Hyg. 2012;87(6):979-84.

2. Clasen T, Schmit WP, Rabie T, Roberts I, Caircross S. Intervention to improve water quality for preventing diarrhea: systematic review and meta-analysis. BMJ. 2007;334(7597):782.

3. $\mathrm{Hu} \mathrm{Z}$, Morton LW, Mahler RL. Bottled water: United States consumers and their perceptions of water quality. Int J Environ Res Public Health. 2011;8(2):565-78.

4. Chen H, Zhang Y, Ma L, Liu F, Zheng W, Shen $\mathrm{Q}$, dkk. Change of water consumption and its potential influential factors in Shanghai: a cross-sectional study. BMC Public Health. 2012;12:450.

5. McLeod L, Bharadwaj L, Waldner C. Risk factors associated with the choice to drink bottled water and tap water in rural Saskatchewan. Int J Environ Res Public Health. 2014;11(2):1626-46.

6. Onjala J, Ndiritu SW, Stage J. Risk perception, choice of drinking water and water treatment: evidence from Kenyan towns. J Water Sanitation Hygiene Development. 2014;4(2):268-80.

7. Doria MF. Factors influencing public perception of drinking water quality. Water Policy. 2010;12:1-19.

8. Sodha SV, Menon M, Trivedi K, Ati A, Figueroa ME, Ainslie R, dkk. Microbiologic effectiveness of boiling and safe water storage in South Sulawesi, Indonesia. J Water Health. 2011;9(3):577-85.

9. Fulazzaky MA. Water quality evaluation system to assess the status and the suitability of the Citarum river water to different uses. Environ Monit Assess. 2010;168(1-4):66984.

10. WHO. Rapid assessment of drinking water quality: a handbook for implementation.
Geneva: WHO; 2012.

11. Peraturan Menteri Kesehatan Republik Indonesia No. 492/MENKES/PER/IV/2010 mengenai Pedoman Kualitas Air Minum.

12. Dupont D, Adamowics WL, Krunpnic A. Differences in water consumption choices in canada: the role of socio-demographics, experiences, and perceptions of health risks. J Water Health. 2010;8(4):671-86.

13. York AM, Barnett A, Wutich A, Crona B. Household bottled water consumption in Phoenix: a lifestyle choice. Water Int. 2011;36(6):708-18.

14. Sikod F, Abba I, Totouom ALF. Household choice of purifying drinking water in Cameroon. Environmental Management Sustainable Development. 2012;1(2):10115.

15. Rufener S, Mäusezahl D, Mosler HJ, Weingartner R. Quality of drinking-water at source and point-of consumption-drinking cup as a high potential recontamination risk: a field study in Bolivia. J Health Popul Nutr. 2010;28(1):34-41.

16. Cabral JPS. Water microbiology, bacterial pathogens and water. Int J Environ Res Public Health. 2010;7(10):3657-703.

17. Saxena G, Bharagava RN, Kaithwas G, Raj A. Microbial indicators, pathogens and methods for their monitoring in water environment. J Water Health. 2015;13(2):319-39.

18. Raksanagara AS, Santanu AM, Sari SYI, Sunjaya DK, Arya IFD, Agustian D. Faktor yang memengaruhi perilaku penggunaan air bersih pada masyarakat kumuh perkotaan berdasar atas integrated behavior model. MKB. 2017;49(2):122-31.

19. Gunnarsdottir MJ, Gardarsson SM, Elliott M, Sigmundsdottir G, Bartram J.Benefits of water safety plans: microbiology, compliance, and public health. Environ Sci Technol. 2012;46(14):7782-9. 